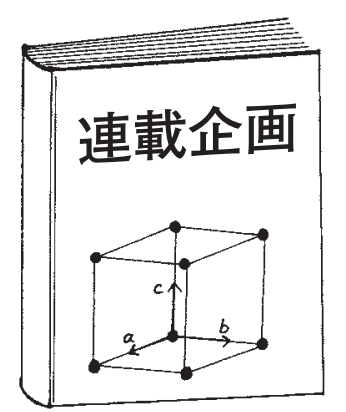

1. はじめに

クライオ電子顕微鏡法 (以降, クライオ電顕) は, 1980 年代にJ. Dubochetらにより開発された氷包埋法の導入 から始まった. $\left.{ }^{1)}, 2\right)$ 水包埋法は, 生体試料をその溶液ごと 急速凍結して非晶質の水の中に埋め込む技術である。こ のことにより, タンパク質などの生体試料を電子顕微鏡 内の高真空から守り, より自然に近い状態で観察できる ようになった。しかし, 電子線による試料損傷は続く大 きな問題であった. R. Hendersonらは, 紫膜 (バクテリオ ロドプシンの二次元結晶）を用いて試料に対する照射電 子線量を最小化することにより, 電子顕微鏡でもタンパ ク質の原子座標を決定することが可能であることを示し た.3そしてさらに, J. Frankらは, 同種のタンパク質の多 数の投影像から立体構造を再構築する単粒子解析法を 開発し, ${ }^{4)}$ 現在の「クライオ電子顕微鏡単粒子解析法」の 基礎を確立した. 2017 年のノーベル化学賞は, これらク ライオ電子顕微鏡法のパイオニアとなった 3 人の研究者 に贈られた。しかし, この技術も約 10 年前は, 生体分子 の構造解析において X線結晶学やNMR 分光法と比べて 分解能が低く,「クライオ電顕マップは, いつもでこぼ こした表面の塊である」という意味から, ブロボロジー (blobology $=$ blob + biology) と喻やされた.

ところが, 最近の目覚ましいクライオ電顕の進歩は, 2つ の主要なイノベーションによりもたらされた. 1つは, 電子直接検出カメラの開発である. 電子直接検出カメラ は, 毎秒数百から数千コマに及ぶ高いフレームレート を実現し, 試料からの散乱電子を 1 つ 1 つピクセルごと に直接読み取ることができる。このことにより, 試料ス
テージのドリフトや電子ビーム照射による試料の動き に起因する画像のボケを, 撮影後に補正することが可能 となった.この「モーション補正」の機能は, 今日, 単粒 子解析では必要不可欠なプロセスとなっている.5),6)もう 1つは, 最尤推定 (maximum likelihood estimation) を用い た画像解析手法の進歩とグラフィックカードによる演算 速度の飛躍的な向上である.7)これらはフーリ工変換な どの計算コストの高いアルゴリズムを用いて, 数百万の 画像を正確に処理することを可能にした，上記2つの技 術革新は, X線結晶解析と NMR 分光法が独占的であっ た構造生物学の世界においてクライオ電子顕微鏡による 革命をもたらした, そしてさらに, 動的な生体分子の構 造変化も原子レベルで分類して解析できる技術になって いる. 本稿では, このクライオ電顕の原理, 基本的な操 作手順，最新の応用例などを紹介する.

\section{2. クライオ電子顕微鏡法による試料観察範囲}

試料の結晶化を必要としないクライオ電顕は, 溶液中 のタンパク質粒子などをより自然に近い状態で構造解析 することができる。このことにより, 生体試料が示すダ イナミックな構造変化に対する豊富な情報が得られる。 さらに, クライオ電顕は, 数十キロダルトンから数メガ ダルトンのタンパク質複合体に至るまで, 幅広い分子量 範囲の構造解析が可能である(図1).また, クライオ電 顕は, X線結晶解析や NMR 分光法と比較してサンプル の形態にも制限が少ないため, 多彩な生体関連試料の観 察に応用できる。例えば, 化合物の微結晶, さまざまな 形状のウイルス粒子, 䋊維状のタンパク質複合体, さら には細菌, 細胞, 組織切片に至るまで, 水包埋さえでき 


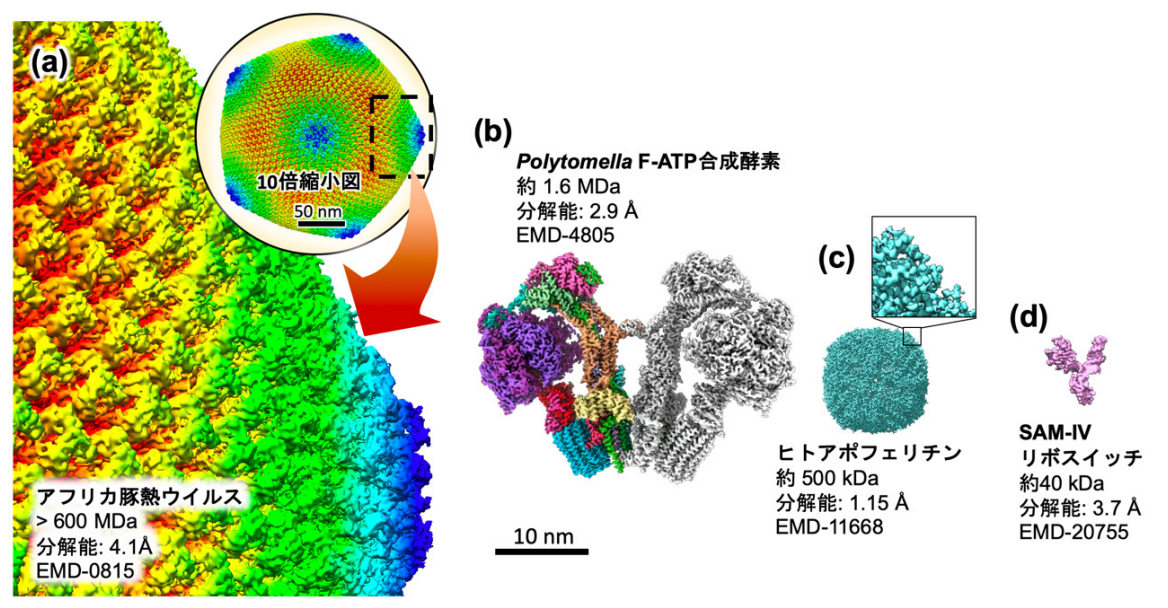

図1 クライオ電子顕微鏡により構造解析された代表的な大小さまざまな生体分子. (Represented various-sized biomolecules determined the atomic structures by cryo-electron microscopy.) (a)から (d)は同じ倍率で表示してい る. (a)アフリカ豚熱ウイルス. ${ }^{9)}$ (b) PolytomellanのF-ATP合成酵素. ${ }^{12}$ (c) ヒトアポフェリチン. ${ }^{13)}$ (d) SAM-IV リボスイッチ.14)

れば基本的に観察可能である. 唯一制限されるのが, 試 料の厚さである。これは電子ビームが試料を多重散乱せ ずに十分に透過できるかどうかの問題で, 測定可能な試 料の厚さは電子顕微鏡の加速電圧にほぼ比例する。単純 に電子線の透過能で言えば, $200 \mathrm{kV}$ 透過型電子顕微鏡 （TEM）の場合は200 nm, $300 \mathrm{kV}$ TEMでは300 nmぐら いまでは観察できると考えてよい.よって, 細胞などの 大きな試料の場合は, 観察できる範囲が比較的薄い細胞 の周辺部に限定されてしまう。この解決策として, 凍結 切片の作製や, 集束イオンビーム (FIB) で凍結試料を薄 〈加工する技術も開発されている. ${ }^{8)}$ また, 単粒子解析で は, 直径約 $260 \mathrm{~nm}$ にもなる巨大ウイルスで, $300 \mathrm{kV}$ のク ライオ電顕を用いて $4.1 \AA$ の分解能で構造解析が行われ ている(図 1a).9)この場合, 電子線の透過能だけでなく, 同一粒子中のフォーカスのズレが問題となる. 粒子全体 を再構築した後に, 粒子を空間的に分けてイメージを再 整列することで,このようにソフト的に分解能を上げる ことに成功した。

一方, 分子量の小さい試料の解析は, 現在, クライオ 電子顕微鏡がもつ課題の 1 つである. クライオ電顕で解 析可能な生体分子の最小サイズは, 試料の許容電子線 量 (Critical electron dose) に対する画像のSN比（シグナ ル／ノイズ比）で決まる，例えば, 原子レベルの分解能 を得るためには200kVの加速電圧に扔いて許容可能な電 子線量は, $20 \mathrm{e}^{-} / \AA^{2}$ 以下であると報告されている. ${ }^{10)} \mathrm{SN}$ 比 は電子線量に比例するので, 小さな分子の場合は必然的 にSN比が下がってしまう。電子線照射量の制限を考慮 した画像の SN 比から計算すると, 約 $38 \mathrm{kDa}$ までが解析 可能とされている. ${ }^{11)}$ 現在, 近原子分解能で単粒子解析 がされている一番小さい生体分子は, $40 \mathrm{kDa}$ の核酸のア ポSAM-IVリボスイッチ (図 1d) である. ${ }^{14)} 1$ つの解決策
として, 電子顕微鏡の加速電圧を下げることが考えられ る. 例えば加速電圧を $200 \mathrm{kV}$ から $100 \mathrm{kV}$ へ下げると, 電子線の散乱断面積が約 1.5 倍上がるため, 得られる画 像の SN 比も改善される. ところが, 同時に試料の許容 電子線量が下がることに加えて, 電子の平均自由行程が 約 $1 / 2$ となるため多重散乱効果も上がってしまう.10)より 小さな分子をクライオ電顕で解析するためには, 試料は できる限り薄くし, 少ない電子線量で SN比だけを上げ られるような新たな光学系の開発が必要である.

\section{3. さまざまなクライオ電子顕微鏡法}

今日, クライオ電顕単粒子解析が脚光を浴びているが, クライオ電顕法による生体分子の構造解析には, 単粒子 解析に加えて, 電子線結晶解析, 電子線卜モグラフィー, 微結晶電子線回折なども用いられる. このような点で, ク ライオ電顕はマルチモダリティーであると言える.

クライオ電顕で最初に原子モデル構築を達成したの は, 電子線結晶解析である. ${ }^{3)}$ タンパク質の二次元結晶を 傾斜させて, 高分解能電顕画像と電子線回折像を独立 に収集し, 電顕画像からの位相情報と電子線回折像か らの振幅を使って, 逆空間でマージされた構造情報の逆 フーリエ変換を可能にした，しかし，良質のタンパク質 二次元結晶を作製することは難しく, そこが現在ボトル ネックとなっている.

電子線卜モグラフィーは, 1990 年代に電顕用 CCD カ メラの普及に伴って, 実用化が急速に進んだ. 試料の連 続傾斜像を試料ステージを連続して傾斜させることに よって収集し，これを逆投影することでもとの立体構造 を再構築する。単粒子解析が苦手とする構造変化を伴う タンパク質粒子の解析などに有効な方法である. 個々の 粒子を独立に三次元再構築し, 三次元で粒子をクラス 
分け（サブトモグラム平均化）することで，タンパク質 の構造変化を分離して解析する。しかし, 同一試料から 60 枚以上の画像を収集する必要があるため, この間に試 料は大きくダメージを受け, 高分解能の解析は難しい. また,この手法はX線 CTなどとは異なり, 試料ステー ジがさ 70 度程度までしか傾斜できないため, ミッシン グウェッジと呼ばれる情報欠損角度領域が生まれる。し かし, 個々の粒子をサブトモグラム平均化することで, ミッシングウェッジの問題を最小にすることができる.

最後に, 微結晶電子線回折 (Micro Electron Diffraction $($ MicroED $))$ は, 微小な三次元結晶を電子線回折を用い て解析する方法である.この手法により，X線ではデー 夕収集が困難であった微結晶から構造決定が可能に

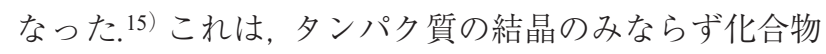
の微結晶にも応用できる。ただし,これには精度の高い 試料傾斜ステージが必要となる.

以上, 紹介した手法は, 単粒子解析を補う型で, クラ イオ電顕構造解析の適応範囲を大きく広げている.

\section{4. 試料グリッドの作製}

\section{1 試料の水包埋}

クライオ電顕では, タンパク質溶液などを, 膜穴グ リッド上で急速凍結して作製される。皇方法は，グ ロー放電などによって膜穴グリッドに親水化処理を施 した後, 1〜3 $\mu \mathrm{L}$ の試料溶液をグリッドに載せ, 余分な 溶液をろ紙で除去した後, グリッドを液体エタン中に急 速に落下して試料を凍結させる (プランジ凍結) (図2). このことにより, タンパク質試料が非晶質の薄い水の膜 の中に閉じ込められた凍結グリッドができる。これを液 体窒素中で保存し, 必要に応じて取り出してクライオ電 顕に装填してその画像デー夕を収集する。

クライオ電顕に用いられる膜穴グリッドは，さまざ まな導電性素材 (銅, 金, モリブデンなど) に規則的な 穴の開いたカーボン支持膜が貼られている（Quantifoil
(Quantifoil Micro Tools), C-flat (Protochips Inc.)). 支持 膜には通常 10〜 $50 \mathrm{~nm}$ の薄い炭素膜が用いられるが, 電 子線照射による膜の帯電を防止するため，これに5〜 $10 \mathrm{~nm}$ 金薄膜をコートしたもの16)も用いられる.

氷包埋法では, 膜穴に試料が均一に分散することが望 ましいが, 試料粒子の表面電荷によって, 穴の中央に集 まったり，穴以外に吸着したりすることがある，そのよ うな場合には, 陽電荷をもつ物質 (アミルアミンなど), もしくは陰電荷をもつ物質 (吉草酸など) のガス䨌囲気 の中で膜穴グリッドの親水化処理を行うことで改善す る場合がある. ${ }^{17)}$ また, 薄いカーボン支持膜をさらに膜 穴グリッドに貼って, 膜穴に粒子を固定することも行わ れる. Kellyらは機能性頭部基をもつ脂質一重膜を付け た「親和性グリッド」を開発し, 濃度の低い粒子からで も水包埋グリッドを作製できることを報告している. ${ }^{18)}$ 水包埋法で一般的に使われる冷媒は液体エ夕ンであ る。一方, 細胞などの比較的大きな試料を氷包埋する場 合には, エタンとプロパンの混合液が用いられる.19) 純 粋なエタンよりもエタンとプロパンの混合物を使用する ことにより冷却剤の凍結温度を低下させ, 細胞のより深 部まで良好に凍結させることができる。

\section{2 クライオ電顕単粒子解析に適した試料グリッド}

クライオ電顕単粒子解析では, 試料粒子がランダムな 方向を向くのに加えて, できるだけ薄い氷に包埋するこ とが重要である. Nobleらは，さまざまなタンパク質粒 子を氷包埋した試料をトモグラフィー解析することで, 水中でのタンパク質粒子の分布を報告した. ${ }^{20)}$ その結果, 多くのタンパク質粒子が氷膜の界面に集積することを 明らかにした，また，膜穴の水は中心で薄く, 端にいく に従って分厚くなっていることが示された.これらのこ とから, クライオ電顕単粒子解析では, 膜穴の見え方, 粒子の分布の仕方などから水の厚さを判断し, 適切な膜 穴, さらには膜穴内の領域を選択して画像を収集するこ とが重要であることがわかった。

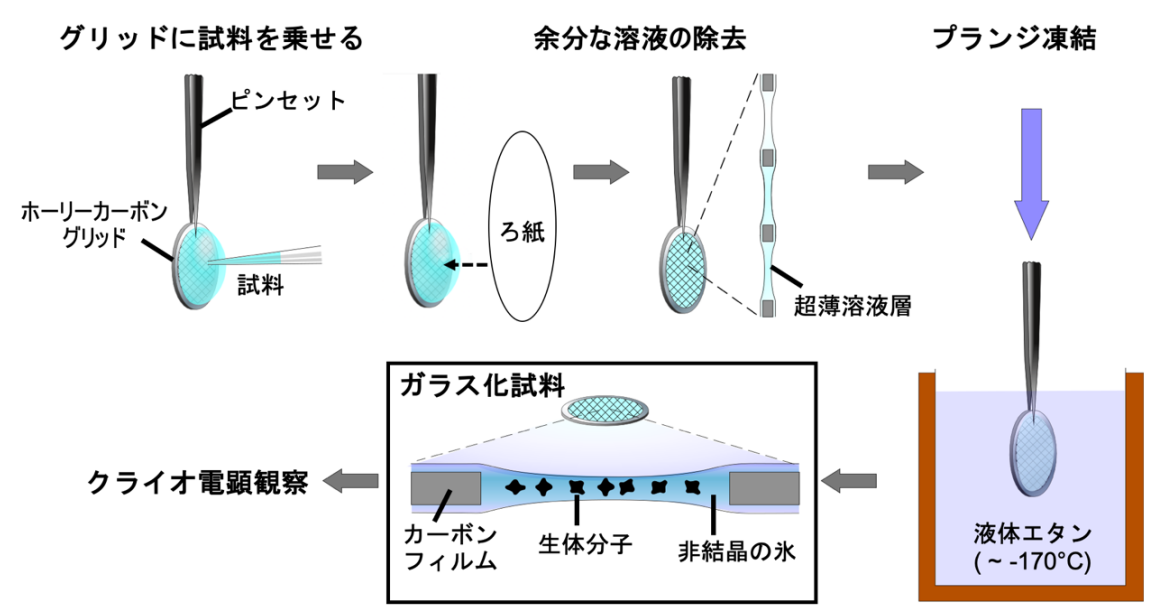

図2 プランジ凍結による氷包埋グリッドの作製. (Preparation of ice-embedding sample grid by plunge-freezing.) 


\section{5. クライオ電顕によるデータの収集}

氷包埋された試料グリッドは, 液体窒素で冷却された クライオワークステーションの中でクライオトランス ファーホルダーもしくは専用のカートリッジに取り付け られ，霜を付けないようにしてクライオ電顕の中に挿入 される.クライオオートローダーを備えたクライオ電顕 （Titan Krios（FEI）, CryoARM (JEOL) など）では，鏡筒 脇に取り付けられたチャンバー内に十数個のグリッドを 同時に装着し，これらを自由に出し入れすることができ る、また，観察するグリッドを選んで自由に鏡筒内に送 り达むことができる。一般的なサイドエントリー型のク ライオトランスファーホルダーでは, 1つのグリッドし か電子顕微鏡にセットすることができず, また, 液体窒 素も約 3 時間ごとに継ぎ足さないといけない.さらには, グリッドをカラムに入れてからステージが安定する（ド リフトがおさまる）まで数十分必要である。これらのこ とから, 現在一般的になりつつある数千枚からの電顕画 像を取得するような目的には, あまり適さなくなって来 ている.

クライオ電顕では, 画像は低照射 (low dose) モードを 使用して撮影される。モードの呼び名は装置メーカーに よりさまざまであるが, その原理は共通で，低倍率または 回折モードでターゲットとなるグリッド上の膜穴の位 置をナビゲートし，その近傍の支持膜上で焦点外れ（デ フォーカス) 量を合わせ，撮影したい領域をあらかじめ 設定した必要最小限の電子線量で露光する。このことに より，試料に対する照射損傷を最小に抑えながら撮影す ることができる，近年の自動化されたクライオ電顕では， 最初に試料グリッドのモンタージュ写真を作成して, そ の中の膜穴の座標を記録し, あとは電子顕微鏡のステー ジがその場所に移動して次々と像を撮影していく。これ らはEPU (Thermo Fisher Scientific) やSerialEM ${ }^{21) な と ゙ の ~}$ ソフトウェアを用いて行われる。また, ハイスループッ 卜に対応するためビーム傾斜機構を用いて, 一回のス テージ移動で複数箇所 (4〜9箇所) の画像を瞬時に撮影 する22)ことも行われている.

クライオ電顕によるデータ取得で重要なことは, 正確 な光軸調整と, 倍率, デフォーカス量, 電子線照射量な どの設定である. 通常の電子顕微鏡の光軸調整に加えて クイラオ電顕で特に重要なのは, 試料に対して平行に電 子線を照射することである。位相コントラストは試料か らの透過光と散乱光の干渉により形成される。電子線が 収束または発散するように試料に照射されると位相コン トラストの低下につながる。また, 並行な電子線が試料 に対して傾いて照射されても，コマ収差などの収差を引 き起こすため, 分解能の低下につながる。 これらは, ク ライオ電顕専用装置では自動で補正できるようになって
いるが，そうでない場合は自身で調整する必要がある。 撮影倍率は, 目標とする分解能により決められる。 力 メラの性能 (DQEなど) にも依存するが, 通常, 目標分 解能の $1 / 4$ (1/2 Nyquist) ぐらいが, カメラの 1 画素に入 るようにするのが目安である。例えば， $2 \AA$ 穴目標の分 解能であれば, 試料上で $0.5 \AA$ がカメラの 1 画素に十分入 るように倍率を設定する。カメラの倍率はそれが取り付 けられている場所で決まる值で, 電子顕微鏡の表示倍率 とは異なるので少し注意が必要である。デフォーカス量 は小さいほうが高分解能のためには良いが, コントラス トが低下するので，試料粒子が確認できるギリギリのと ころに設定する。また, 最終的にコントラスト伝達関数 (CTF) (後述)の影響を最小にするためには, その前後で 若干異なるデフォーカス量の像を撮影しておく必要があ る. 電子線量は, 試料がダメージを受けない範囲で設定 するものであるが, 電子直接検出カメラが使われるよう になってからは, 電子カウンティングできる線量が優先 され，露光時間によって最終的に調節されるのが一般的 となった。

その他，エネルギーフィルターのスリット幅の設定な ど, 高分解能の電顕像を収集するためには, 装置に依存 した調整が必要となる。

\section{6. 単粒子解析}

\section{1 単粒子解析の原理}

クライオ電顕単粒子解析は, 前述の技術革新により夕 ンパク質試料を結晶化することなく構造決定ができる ようになったため, 近年急速に普及した，単粒子解析の 原理は，計算機の中で個々のタンパク質粒子の画像を整 列させて仮想的なタンパク質結晶を作ることと考えて良 い. 実際には, タンパク質粒子の向きの異なる投影像を 多数収集して, これを計算機の中で整列化させ, 個々の 投影角度を推定して逆投影することで, 元の三次元の粒 子構造を再構築する(図3)。また, 同じ角度投影像は平均 化されて SN 比を上げることができる. 現在では, 電子顕 微鏡の自動化が進み, 構造決定に用いられる単粒子解析 のデータセットは, 数千から数万の電顕像で構成され, 個々の画像からは, 数百に及ぶ異なる向きのタンパク質 粒子像がピックアップされることが通常となっている.

一方で，単粒子解析には必要な仮定がある。その1つ は，どの投影像も同型の粒子からのものであるというこ とである.つまり, 別のタンパク質粒子が混ざっていて もいけないし，タンパク質粒子が異なるコンフォメー ションを取ってもいけない。そしてもう1つは，タンパ ク質粒子が包埋した氷の中でランダムな向きを取って いるということである。これは，タンパク質粒子が非対 称な構造の場合や, 局所的にチャージをもつような場合 には, ランダムな向きを取らないことがよくある。プリ 


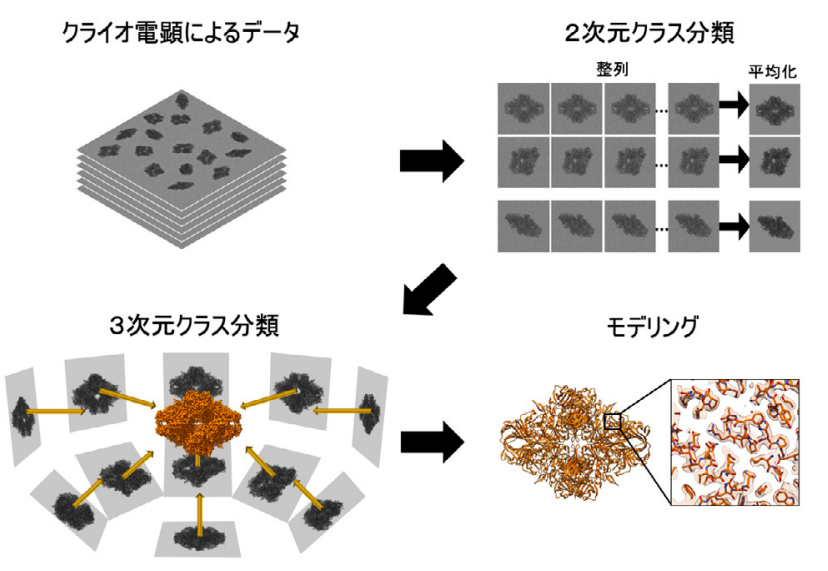

図3クライオ電顕電子顕微鏡単粒子解析の原理. (Principle of single particle analysis.)

ファードオリエンテーションと呼ばれ，うまく三次元再 構成できない原因となる。以上のような仮定を満たさな い試料は, 基本的に単粒子解析により構造決定すること ができない.しかし, 後述するように, 解析アルゴリズ ムの進展により, わずかなコンフォメーションの変化で あれば，これを分離して解析することが可能になってき ている。

\section{2 単粒子解析の基本手順}

単粒子解析の基本手順を図 4 に示す. 以下, 各々のプ ロセスについて説明する。

\subsection{1 モーション補正}

クライオ電顕単粒子解析で一般的に用いられている 電子直接検出カメラでは, 電顕像をムービーで記録し, 個々のムービーフレーム間での粒子像のズレ（ドリフト） を補正して, 一枚の電顕画像を作り直す。そして, 必要に 応じて電子線損傷量に対する重み付けも行われる。この ことにより, 高分解能の電顕画像を得ることができる. モーション補正は, MotoinCor2, ${ }^{23)}$ Unblur, ${ }^{24)}$ Direct detector utilities $^{25)}$ などのソフトウェアを用いて行うことができる.

\subsubsection{CTF補正}

クライオ電子顕微鏡の画像は, 電磁レンズの収差のた めに周波数空間上で大きく変調を受けている.これはコン トラスト伝達関数 (Contrast Transfer Function, CTF) とし て定式化されており, 特にクライオ電顕ではサイン関数 で表される位相コントラスト伝達関数に従って, コント ラストの反転が起こる. CTFは収差とデフォーカス量に よって決まる関数なので, デフォーカス量の異なる画像 を平均化もしくはマージするためには, その前に画像ご とにCTFを推定し, これを補正する必要がある. 現在で は, これらを自動化したソフトウェア (ctffind, ${ }^{26)}$ getf, ${ }^{27)}$ e2ctf.py $\left.{ }^{28)}\right)$ が利用できるようになっており, 数千枚の画 像データでもバッチ処理で行えるようになっている.

\section{2 .3 電顕画像からの粒子像の抽出}

現在の単粒子解析では, 多くの場合数万をはるかに超

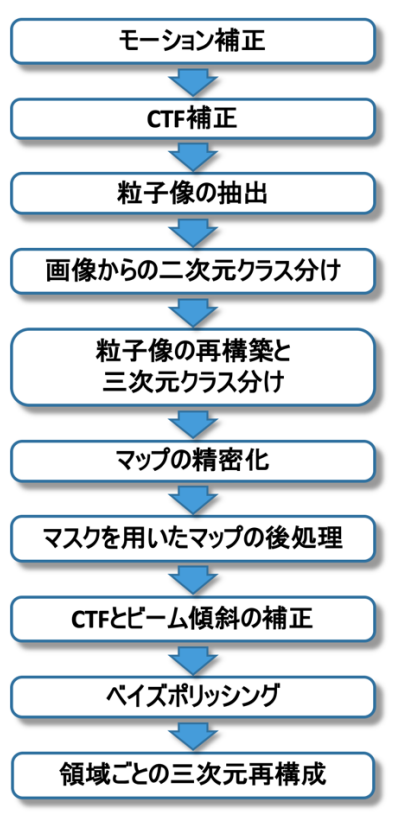

図4 単粒子解析の手順. (Image processing work flow of single particle analysis.)

える粒子像が三次元再構成に用いられる。これらを人の 手で抽出するのは不可能である. そこで, ガウシアン - ラ プラシアンフィルター $(\mathrm{LoG})$ を用いて粒子を検出する ものや, 教師画像を用いるものなど, さまざまなタイプ の自動抽出ソフトウェアが開発されている (Gautomatch (https://www.mrc-lmb.cam.ac.uk/kzhang/Gautomatch/), e2boxer.py, ${ }^{29)}$ Relion-autopick, ${ }^{7)}$ FindEM, ${ }^{30)}$ Signature $\left.{ }^{31)}\right)$. Relion-autopickでは, 最初にLoGを用いて数枚の電顕像 から粒子像を抽出し, この二次元クラス分けを行って主 要な平均化像を作製して, これを教師像として残りの電 顕像から粒子を自動で抽出することが行われる。これら のソフトウェアはいずれもバッチ処理に対応しており, 数千枚の画像からの粒子の抽出も自動で行ってくれる.

\section{2 .4 画像の二次元クラス分け}

個々の粒子像はダメージを避けるため低い電子線で 記録されているため, SN 比が非常に低い画像になって いる，そこで，これらを分類して平均化することでSN比 を上げる必要がある。この操作は, 三次元再構成のため に必要な投影像が含まれているかどうかを確認するとと もに, 間違って抽出された目的粒子以外のものを除くた めにも用いられる。この操作ステップから計算時間を短 くするため, 画像を縮小 (ビンニング) して行われるこ とが多い.

\section{2 .5 粒子像の再構築と三次元クラス分け}

単粒子解析では未知の粒子像を立体再構築する場合, 先の二次元クラス分けした平均像の中からより鮮明な ものをいくつか選んで粒子の初期三次元モデルを構築 し, これを基に粒子像を再構築していく.しかし, 中に は粒子中の突出した構造に引きずられて, 目標とは異な 
る構造に収束してしまうことがある。再構成像の三次元 クラス分けは, いくつかの可能な三次元像を生成するこ とで, 誤った構造の収束を防ぐ. また, この機能は後述 するように粒子中のわずかな構造変化を分類することに も使われる。

\subsection{6 マップの精密化}

上述の操作で確からしい三次元粒子像を選択するこ とできたら, 粒子画像の縮小率をもとに戻して, 大元の ムービーフレームを用いてマップの精密化が行われる. ここでは, 再構築像の逆投影と元々の粒子像とを比較す ることで, 電顕マップの分解能を上げていく.これはそ の操作からプロジェクションマッチングと呼ばれる。プ ロジェクションマッチングは徐々に逆投影角度を細かく して進められ, 最終的に分解能がそれ以上向上しなくな るまで繰り返される。

\subsection{7 マスクを用いたマップの後処理}

マップの精密化が完了したら, 適当な B-Factorを適応 してマップのシャープニングを行う. B-Factorはソフト ウェアが推定した值を使うこともできるし，マニュアル でセットすることもできる，さらに，分解能を見積もる ために, 粒子よりも少し大きめのマスクをかけた上で再 度三次元再構築を行う。このことで, 粒子と周辺の溶液 とをはっきりと区別して三次元再構成することができ, 分解能をより正確に推定することが可能となる.

\subsubsection{CTFとビーム傾斜の補正}

ここでは, さらにマップの分解能を上げるため, 三次 元再構成に使われた個々の粒子の CTF 補正が行われる. 先に行ったCTF補正は, 電顕像単位で行ったもので, 実 際には1枚の電顕像の中でも粒子によってデフォーカ スが変わるからである。これには, 個々の粒子について CTFを推定し, これを補正する。また, 試料に対して斜 めに電子線が照射されて記録された電顕像は, 1つの粒 子像の中で左右で位相がわずかにズレてしまうので，こ れも個々の粒子像について補正される。

\section{2 .9 ベイズポリッシング}

さらに分解能を向上させる手段として, 三次元再構成 に用いられた個々の粒子像について, 再度, ベイズ推定 を用いてもとの電顕画像ムービーフレーム内における モーション補正を行うことができる。まず訓練モードに よりモーションについての事前情報が推定できたら, こ れをすべての粒子のムービーフレームに適応し, これに より高精細の粒子像が再構築される。

\section{2 .10 領域ごとの三次元再構成}

柔軟な構造をもつタンパク質は, 全体的には高い分解 能のマップが得られても, 部分的には分解能の低い領域 が生じる，そのような場合は，その領域だけにフォーカ スして三次元クラス分けや再精密化を行うことができ る.このプロセスにより構造の一部分のダイナミックを 日本結晶学会誌 第 63 巻 第2号 $(2021)$
調べることが可能であるとともに, 全体の分解能を高め ることもできる.

以上, 一連の単粒子解析の操作はRelion, ${ }^{7)}$ cryoSPARC, ${ }^{32)}$ cisTEM ${ }^{33)}$ Spire ${ }^{34)}$ EMAN229) などのソフトウェアを用い て行うことができる。これらソフトウェアの最大の特徵 は, GUIにより各操作が画面上で順番に指示され, 最終 的な電顕マップの作製までたどり着けることである.

\section{7. 分解能の測定, モデル構築, 評価}

電顕マップの分解能の1つの決定方法として, フーリ エシェル相関 (Fourier shell correlation (FSC)) がある. 粒子像を無作為に半分に分けて独立に三次元再構成を 行う。そして，2つの電顕マップの相互相関係数を空間 周波数に対してプロットすることによって決定される. Rosenthal と Hendersonは, 最終的にすべての粒子を用い て構築されたマップの分解能が, FSCのために使用され た半分の粒子数のマップよりも高いという事実に基つい て, $\mathrm{FSC}=0.143$ を導入した. ${ }^{35)}$ そして，これがX線結晶 学において用いられる基準とおおむね一致することか

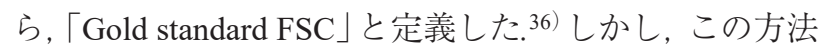
は実際取り得る構造とは関係なく決まる值であることか ら, 一般には, 構築した原子モデルから計算したマップ との FSC $=0.5$ を合わせて評価することも行われる。 こ れは先と区別して Map-to-Model FSCと呼ばれる。また, 実際にはマップは局所的に分解能が異なることから，「局 所」分解能 (Local resolution) を表示することもよく行わ れる. ${ }^{37)}$

クライオ電顕による生体分子構造解析の最終的な目 的は, 生体分子の分子構造の決定である. 分解能が $3 \AA$ を超えるマップであれば, タンパク質の一次構造から de novo モデル構築も可能であるが, 分解能が $3 \sim 4 \AA$ の マップであれば, タンパク質であればポリアラニンなど を用いて主鎖のモデル推定し， $\alpha$ ヘルックスや $\beta$ シート などの二次構造や芳香環などの大きな側鎖をもつアミノ 酸を目印としてモデルを構築することになる。さらに低 分解能 (4 A 未満) では, 二次構造の同定から初めて, 分 子動力学 38) やノーマルモード解析 ${ }^{39)}$ のような物理化学 的制約を組み込んだ手法を組み合わせる必要がある。精 密化されたモデルは，X線結晶解析による構造モデルで 行われるのと同様に, さまざまな統計值を参考に原子座 標の立体障害をチェックする検証ツールで評価される.40)

\section{8. クライオ電顕の応用例}

\section{1 動的分子の観察}

多くのタンパク質およびタンパク質複合体は, 溶液中 で複数の立体構造をとり, また, 構造を変化させてリガ ンドや金属を分子内に取り达んだりする，そこで，構造 生物学では単一のタンパク質構造だけではなく溶液の中 
での動的構造の解明も重要視されてきた，溶液中での夕 ンパク質のダイナミックスはNMR 分光法を用いること で観察が可能であるが, 解析できるタンパク質の分子量 に制限 (25 kD 以下) がある. ${ }^{41), 42}$ ) 最近, X線結晶解析で も X線自由電子レーザー（XFEL）を用いていることで 時分割解析によるタンパク質のダイナミックスの研究が 行われている、43),44) しかし, 結晶中でのタンパク質での ダイナミックスの分析に限られる。 また, 高速原子間力 顕微鏡（高速 AFM）を用いれば, 分子スケールの構造変 化や分子間の相互作用などの観察をリアルタイムで行 えるが, ${ }^{45}$ 空間分解能の制限で原子レベルの構造変化ま でを把握することはできない.このような中でクライオ 電顕はタンパク質のダイナミックスを解析するための 新たなツールになってきた. クライオ電顕では, 構造の 「三次元クラス分け」という高度なアルゴリズム機能を 用いて, タンパク質粒子中のわずかな構造変化を分離し て解析することは可能である，その一例として，Murphy らは, F-ATP 合成酵素に执てて13個すべての回転状態の 構造を三次元クラス分けして近原子分解能で報告した (図 1b, 図 5a).12) この構造解析は, ATP 合成酵素の柔軟 で可逆的な構造変化に依存したATP合成プロセスを詳 細に説明した，また，溶液状態の試料をそのまま観察で きることは, 生体内での環境を仮定した条件で, タンパ ク質のコンフォメーションを確認することができる。 そ の一例として, ノロウイルスが環境条件により構造変化 をする様子が可視化された（図5b).46）ノロウイルスは, 酸性条件下で金属イオンのリッチな状態に置くと, 外側 の突起が内側の殼に密着する。一方で, アルカリ性条件 下で金属イオンがない状態に置くと, 突起がシェルから
離れて伸びる，さらに中性の場合は，1つの粒子が両方 の状態をもつことを示され, 粒子の構造変化がどのよう に行われるのかがクライオ電顕を用いて確認された。

\section{2 膜タンパク質の構造解析}

結晶化が困難でX線結晶学では構造解析ができなかっ た膜タンパク質試料が, クライオ電顕単粒子解析によっ て解かれた事例は多くある。しかし, クライオ電顕でも 分散よく安定に膜タンパク質を可溶化する必要があり, そのためには多様な工夫が必要である. 膜タンパク質の 可溶化にはさまざまな界面活性剤が用いられる。しかし, これらはミセルとして溶液中に残るために, クライオ電 顕観察においてはバックグラウンドノイズを高める原因 になる。これを改善する目的で, 膜タンパク質の三次元 結晶化などでも用いられる Amphipol P LMNGが使われ ることがある. Amphipol は両親媒性ポリマーで, 膜タン パク質の疎水界面との親和性が高いことから, 精製で用 いた界面活性剤を Amphipolに置換した後, 界面活性剂 を含まない溶液に置き換えることができる. Sheng らは Amphipolを用いてクラミドモナスの光化学系II (PSII) の膜タンパク質超複合体を安定的に精製することに成 功し, 近原子分解能の構造を明らかにした ${ }^{47)}$ ところが, Amphipolは, 膜にかなり強固に結合するため, 酵素活性 が急激に失われるというデメリットも示された.48) これに 対して, LMNGは, CMC (臨界ミセル濃度) が $0.001 \%$ と 非常に低いことから, クライオ電顕観察においてかなり バックグラウンドの影響を下げることができる. 高熱菌 V-ATPaseの構造解析では, $0.003 \%$ LMNGが用いられ 構造決定につながった ${ }^{49)}$ 一方, できる限り自然の状態 で膜タンパク質を構造解析したい場合には, ナノディス (a)

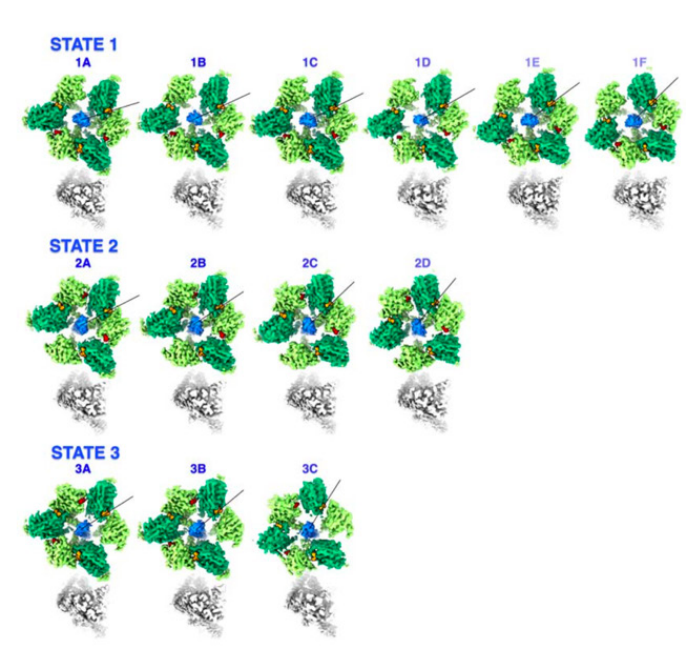

(b)

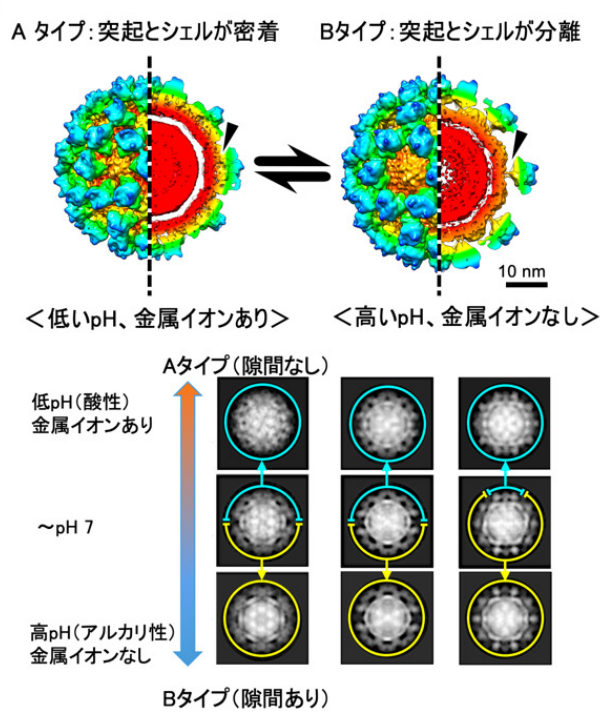

図5 クライオ電顕による動的分子の構造研究. (Structural studies of dynamic molecules by cryo-EM.) (a) F-ATP 合成 酵素に扔いて三次元クラス分けされた 13 個の異なる構造の断面. ${ }^{12)}$ (b) pH と金属イオンによって構造変化す るノロウイルスキャプシド. ${ }^{38)}$ 


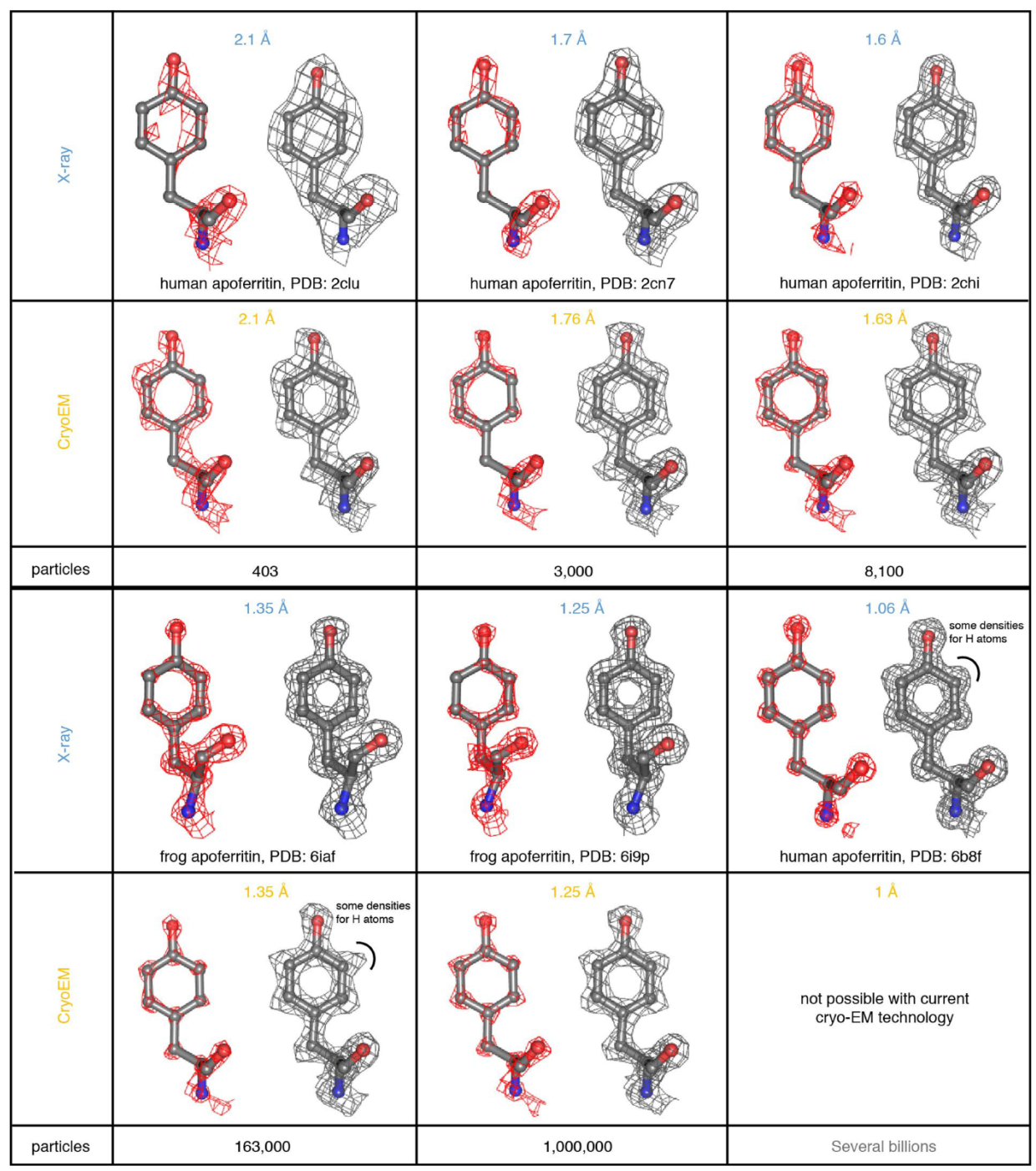

図6 X 線結晶解析とクライオ電顕とのマップの比較. ${ }^{13)}$ (Comparing atomic resolution features obtained by X-ray crystallography and cryo-EM.)

ク (nanodisk) が用いられる。この方法を用いて, TRPV1 チャネルがリガンドの結合によって開口するメカニズム が明らかにされた.50)

\section{3 クライオ電顕による原子分解能マップ}

Yipらはモノクロメーターを備えたクライオ電子顕微 鏡を用いて $1.25 \AA$ 分解能のアポフェリチンの電顕マップ を報告した.13) そして, これをX線結晶解析による電子 密度マップと比較した. X線では水素原子に起因する密 度は $1.06 \AA$ のマップでも見られないが, 電顕マップでは $1.35 \AA$ のマップでそれを確認することができた（図6). また, X線のマップでは個々の原子を $1.06 \AA$ のマップで 初めて分離して観察することができるが, 電顕マップで は $1.35 \AA$ のマップでそれを確認することができた。 これ らはX線の電子密度マップと電顕のポテンシャルマップ との違いと考えられる。この結果は, 構造生物学に新し い研究分野を開いたと言える。

\section{9. 結論と展望}

本稿は, クライオ電子顕微鏡法の概要を説明し, この 分野への新規参入者への手助けとなるように書かれた. ここで紹介したように, クライオ電子顕微鏡による構造 解析はようやく必要最低限の技術が出揃い, スタートラ インに立ったと言える。ここですべてを紹介しきれな かったようにクライオ電顕にはまだまだ構造解析のため のポテンシャルが備わっており,これを武器に未開拓な 分野へさらに進出していけるものと期待する. 是非, 本 稿を参考にして, 新しい構造生物学の分野をわれわれと ともに発展させて頂ければ幸いである。

\section{文 献}

1) M. Adrian, et al.: Nature 308, 32 (1984).

2) J. Dubochet, et al.: Q. Rev. Biophys. 21, 129 (1988).

3) R. Henderson: J. Mol. Biol. 213, 899 (1990).

4) J. Frank: Three-Dimensional Electron Microscopy of Macromolecular Assemblies: Visualization of Biological Molecules in Their Native 
State, Oxford University Press (2006).

5) A. F. Brilot, et al.: J. Struct. Biol. 177, 630 (2012).

6) X. Li, et al.: Nat. Methods 10, 584 (2013).

7) S. H. Scheres: J. Struct. Biol. 180, 519 (2012).

8) F. R. Wagnerm, et al.: Nat. Protoc. 15, 2041 (2020).

9) N. Wang, et al.: Science 366, 640 (2019).

10) L. A. Baker, et al.: Methods Enzymol. 481, 371 (2010).

11) R. Henderson: Q. Rev. Biophys. 28, 171 (1995).

12) B. J. Murphy, et al.: Science 364, 6446 (2019).

13) K. M. Yip, et al:: Nature 587, 157 (2020).

14) K. Zhang, el al.: Nat Commun. 10, 5511 (2019).

15) D. Shi, et al.: Elife, 2, e01345 (2013).

16) C. J. Russo, et al.: Science 346, 1377 (2014).

17) R. A. Grassucci, et al.: Nat. Protoc. 2, 3239 (2007).

18) D. F. Kelly, et al.: J. Mol. Biol. 400, 675 (2010).

19) W. F. Tivol, et al.: Microsc. Microanal. 14, 375 (2008).

20) A. J. Noble, et al.: Elife, 7, e34257 (2018).

21) D. N. Mastronarde: J. Struct. Biol. 152, 36 (2005).

22) C. Wu, et al.: J. Struct. Biol. 208, 107396 (2019).

23) S. Q. Zheng, et al.: Nat. Methods 14, 331 (2017).

24) A. F. Brilot, et al.: J. Struct. Biol. 177, 630 (2012).

25) Z. Ripstein, et al.: Methods Enzymol. 579, 103 (2016).

26） A. N. Rohou, et al.: J. Struct. Biol. 192, 216 (2015).

27) K. Zhang, et al.: J. Struct. Biol. 193, 1 (2016).

28) J. M. Bell, et al.: Methods 100, 25 (2016).

29) G. Tang, et al.: J. Struct. Biol. 157, 38 (2007).

30) A. M. Roseman: J. Struct. Biol. 145, 91 (2004).

31) J. Z. Chen, et al.: J. Struct. Biol. 157, 168 (2007).

32) A. Punjani, et al.: Nat. Methods 14, 290 (2017).

33) N. Grigorieff: Methods Enzymol. 579, 191 (2016).

34) T. Moriya, et al.: J. Vis. Exp. 123, e55448 (2017).

35) P. B. Rosenthal, et al.: J. Mol. Biol. 333, 721 (2003).

36) S. Chen, et al.: Ultramicroscopy 135, 24 (2013).

37) Y. Kayama, et al.: Sci. Rep. 11, 1 (2021).

38) B. Webb, et al.: Curr. Protoc. Bioinforma 54, 5.6 .1 (2016).

39) Q. Jin, et al.: Structure 22, 496 (2014).

40) K. Murata, et al.: Biochim. Biophys. Acta, Mol. Cell Res. 1862, 324 (2018).

41) T. Sugiki, et al.: Comput. Struct. Biotechnol. J. 15, 328 (2017).

42) A. Dubey, et al.: J. Biomol. NMR 74, 479 (2020).

43) J. H. Park, et al.: Int. J. Mol. Sci. 20, 1943 (2019).
44) J. C. H. Spence: IUCrJ 4, 322 (2017).

45) T. Ando, et al.: Prog. Surf. Sci. 83, 337 (2008).

46) C. Song, et al.: PLoS Pathogens 16, e1008619 (2020).

47) X. Sheng, et al:: Nat. Plants 5, 1320 (2019).

48） R. N. Burton-Smith, et al.: J. Biol. Chem. 294, 15003 (2019).

49) A. Nakanishi, et al.: Nat. Commun. 9, 1 (2018).

50) Y. Gao, et al.: Nature 534, 347 (2916).

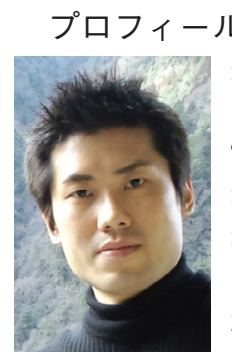

宋 致宖 Chihong SONG

自然科学研究機構 生命創成探究センター

The Exploratory Research Center on Life and Living Systems (ExCELLS), National Institutes of Natural Sciences

干 448-8585 愛知県岡崎市明大寺町字西郷中 38

38 Nihsigonaka, Myodaiji, Okazaki, Aichi 444-8585, Japan

TEL : 0564-55-7894

FAX : 0564-55-7895

e-mail: chsong@nips.ac.jp

最終学歴：博士 (理学)

専門分野: 構造生物学, 細胞生物学

現在の研究テーマ: 電子顕微鏡による構造解析

趣味：トモグラフィー解析

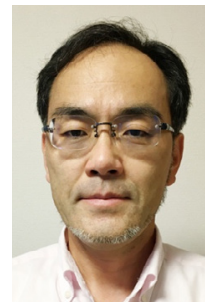

村田和義 Kazuyoshi MURATA

自然科学研究機構 生命創成探究センター

The Exploratory Research Center on Life and Living Systems (ExCELLS), National Institutes of Natural Sciences

T 448-8585 愛知県岡崎市明大寺町字西郷中 38

38 Nihsigonaka, Myodaiji, Okazaki, Aichi 444-8585, Japan

TEL : 0564-55-7893

FAX : 0564-55-7895

e-mail:kazum@nips.ac.jp

最終学歴: 博士 (理学)

専門分野: 構造生物学, 電子顕微鏡学

現在の研究テーマ: クライオ電子顕微鏡による 生体分子の構造解析

趣味：ひみつ 